\title{
Moderating Effect of Political Embeddedness on the Relationship between Resources Base and Quality of CSR Disclosure in China
}

\author{
Fawad Rauf ${ }^{1,2, *}$, Cosmina Lelia Voinea ${ }^{2}{ }^{\circ}$, Hammad Bin Azam Hashmi ${ }^{1}$ and \\ Cosmin Fratostiteanu ${ }^{3}$ \\ 1 School of Management, Xi'an Jiaotong University, Xi'an 710049, China; hammad.shah046@gmail.com \\ 2 Faculty of Management, Open University of the Netherlands, P.O. Box 2960, 6401 DL Heerlen, \\ The Netherlands; cosmina.voinea@ou.nl \\ 3 Faculty of Economics and Business Administration, University of Craiova, 200396 Craiova, Romania; \\ cosminfratostiteanu@yahoo.com \\ * Correspondence: fawadraufkhan@gmail.com
}

Received: 8 March 2020; Accepted: 13 April 2020; Published: 21 April 2020

\begin{abstract}
This study investigates the relationship between corporate political embeddedness and the quality of corporate social responsibility (CSR) disclosure for Chinese listed A-share firms. The study applies the legitimacy theory to the diffusion of CSR in Chinese companies, which otherwise have a differentiating characteristic from Western companies: part of their property being owned by the government. We used 21,295 firm-year observations from Chinese listed firms between 2010 and 2016. The findings reveal that political embeddedness moderates the relationship between firms' resource base and CSR disclosure quality, such that the effect of resource base on CSR quality was found to be weak for firms with a higher level of political embeddedness. Furthermore, firms with a higher level of political embeddedness will disclose CSR with a lower quality, whilst firms with a higher resource base report CSR with a higher quality. The findings of this study contribute significantly to the literature on CSR disclosure by recognizing the positive impact of political embeddedness and resource base on CSR disclosure quality.
\end{abstract}

Keywords: corporate social responsibility (CSR); disclosure quality; CSR reports; resource base; political embeddedness

\section{Introduction}

Corporate political embeddedness can be treated as a strategy for social benefit and may allow firms to get political attention and sponsorships [1,2]. Politically embedded firms are firms which have strong relationships or ties with government, either through government ownership or through network connections [3,4]. Politically connected companies conduct variant design forms based on institutional and political context strategies [5,6]. Studies suggest that countries with a weak institutional environment [7] generate an essential need for a strong connection between political leaders and firms [6,8]. Previous studies have examined the benefits accruing to firms due to political embeddedness [4,9]; these benefits can be reflected in financial $[10,11]$, strategic $[12,13]$, and environmental performance [14]. However, little attention has been given to the connection between political involvement and corporate social responsibility (CSR) disclosure [15,16], or to the political pervasiveness and sponsors linked to that relationship [17-21]. CSR disclosure quality has attracted major attention in the accounting CSR-related area since the publication of an exceptional paper by [22]. Hasseldine and Toms [22] argued that CSR disclosure quality has a strong influence on the development of the environmental character of policy-making and suggested initially that 
the quality of CSR disclosure marginally measures shareholder investor groups. They advise that an additional inquiry into the influence of CSR disclosure policy and stock market value might be particularly beneficial in the pertinence of CSR disclosure quality. Boutin-Dufresne and Darren D. Lee $[23,24]$ rationalize that a higher quality CSR disclosure is linked with lower distinguishing risk. The disclosure/publication of a CSR report by a firm obliges the firm to subsequently decline information of abnormality inside the business. Seong Y. Cho and Ray J. Pfeiffer Jr [25] furthermore provide empirical evidence that firms with high quality CSR disclosure issue additional information, as they indicate the benefit of a helpful reputation in the eyes of stakeholders and shareholders. A firm that achieves substantial environmental performance is able to disclose in their CSR reports extra information about environmental matters by this reducing information abnormality [26,27]. The quality of CSR disclosure in the financial market not only controls the sustainable development of the firm but also has an influential effect on the performance for its investors. A high quality CSR disclosure offers a positive proposition for influential stakeholders and subsequently they will appreciate the company's predictable rate of return [28]. Focused on the behavior sample of institutional investors, Harrison Hong and Henry L. Petersen [29,30] powerfully show that these investors sponsor firms with high quality CSR reports. Founded on numerous cases from the US and Spain, Marlene plumlee and Carmelo Reverte [31,32] highlight that CSR quality is related to business value. Therefore, a higher quality of CSR disclosure indicates a better chance for financing and investors' prospects.

Moreover, concentrating on the human rights practices of ten Chinese state-claimed endeavors, Glen Whelan and Judy Muthuri [33] found that weights at national and intra-organizational levels are essential to adjustments within the universal rules of human rights. According to several authors $[15,17,20]$, corporations that are directly and regularly impacted by state governmental issues and political elites are prone to utilize CSR disclosure to manage political issues.

Existing CSR studies in China show that CSR disclosures have received high attention and pressure from controllers and general field related organizations. Moreover, there is a marvelous development in the practical research on CSR disclosures in China [34]. According to China's political structure, the government holds authority over every aspect of the business environment, and aims to promote CSR as a desired corporate practice [35].

Since the 1980s, the majority of Chinese firms have been transformed from state-owned enterprises into listed firms, although the government often remains the majority shareholder, continuing to hold proprietorship and dominate these organizations [36,37]. Consequently, political embeddedness linking the state, the national legislative body, and a corporation's board of directors is very common $[38,39]$. Previous studies have separately focused on the effects of government ownership [39] and political connections [38-40] on corporate policies and strategies. This study fills in this gap by examining the influence of both forms of political embeddedness on CSR disclosure quality, and makes an effort to examine the relationship between political embeddedness and CSR disclosure quality in the context of China.

Firms with a high level of political embeddedness, either through political networking or due to state ownership, may access more resources from central government after strict scrutiny $[3,40]$. For instance, in China, firms which have strong political connections and which have strong government influence, are further affected in their business activities [41]. Even though the nation has substantially moved towards a more market-oriented framework, the Chinese economy is still characterized by solid government control $[18,42]$ both at the market and industry level, as well as at the organizational level (through state majority ownership as well as state influence) [36,37]. Moreover, there are still strong political connections present between the state and firms' management [38,39].

Government regulations and guidelines remain the most important situational factor when analyzing CSR and CSR disclosure [43,44]. In this context, high monitoring and enforcement by the government related to CSR disclosure may in return also provide several benefits to the firms $[3,45]$. However, the state is not the sole decision-maker, because of the divergence in priorities among local and central government [46]. Therefore, the question arises as to how these conflicts among different 
levels of government influence the CSR practices of Chinese firms and how political embeddedness determines the level of firms' involvement in CSR disclosure quality.

The present research will contribute to the existing literature in several ways. Firstly, this study has identified the non-financial factor, political embeddedness, affecting the involvement of Chinese firms in CSR disclosure. It may help policymakers to realize the importance of political embeddedness in influencing firms' decisions related to CSR disclosure. Secondly, this study has determined a comprehensive measure of political embeddedness by incorporating both government ownership and political connections. Finally, this study will help to understand how political embeddedness affects the disclosure practices of the organization in the Chinese governance system.

The rest of the paper is organized as follows: Section 2 consists of a literature review, Section 3 discusses our methodology, and Section 4 documents the empirical part of the paper. We discuss our conclusions, followed by policy implications.

\section{Literature Review and Hypotheses Development}

\subsection{Legitimacy Theory}

CSR disclosure plays a significant role in resolving corporation issues [47]. Studies show that it is very complicated for firms to attract competitive investments and maximize their profit without revealing information about CSR activities [22]. It is generally accepted that firms participating in CSR activities usually disclose relevant CSR information due to the contribution of such disclosure to firms' finances $[48,49]$.

Legitimacy theory asserts that CSR disclosure is due to public pressure and media attention, while social visibility is a result of critical social incidents [50,51]. According to Rob Gray and Simon Lavers [52], social theory, political theory, and economic theory prevail, whilst actually social and political theory are most appropriate and generally used in discussing CSR activities. Legitimacy theory also identifies that the social and political domains are best for analyzing CSR activities [52,53]. Corporations behave according to the norms and values of society, and they can make changes through communication [54,55], performing according to normative and regulative institutional pillars in observing cultural norms, and appropriate rules and regulations. The results of these studies generally acknowledge the applicability of legitimacy theory to understanding the voluntary CSR disclosure practices of companies. Accordingly, the present study attempts to investigate whether legitimacy theory can be used to explain the nature of CSR disclosure in company annual reports.

\subsection{The Relationship between Political Embeddedness and CSR Disclosure Quality}

Political embeddedness refers to a close relationship between firms and political institutions or actors [56]. There is existent literature that has reported that firms in both emerging and developed economies are actively making an effort to embed themselves within political institutions [3,57-60]. However, it is not yet clear how political embeddedness impacts firm performance in an effective way. According to the existing political strategy literature, studies have determined the benefits of political embeddedness in the form of government subsidies [61,62], threat buffering [60], and the low cost bank [63]. Besides these inherent benefits, some studies have reported the positive impact of political embeddedness on financial performance [10,11], strategic performance [12,13], and environmental performance [14]. On the other hand, some studies have reported the negative influences of political embeddedness, like operational inefficiencies due to government $[10,64,65]$.

When it comes to emerging economies, China is considered the best case for studying the role of political embeddedness [3,12]. Although China has made a significant transformation towards a market-based economy over the last few decades, the Chinese economy is still under the strong influence of the government [18,42]. Generally, China offers a well-suited platform to examine the role of political embeddedness on firms' strategic choices, or how government policies affect the strategic orientation of state-owned firms. One of the important aspects of government signal is related to CSR 
activities and promoting sustainable business practices. In this regard, there is well-reported evidence of Chinese government concerns about desired CSR practices $[42,66,67]$. However, in the early period of market transition in China, the central government made fiscal-sharing agreements with local governments. Due to these contracts, local governments were able to participate in regional economic growth, and this participation enhanced their motivation towards the promotion of growth [68]. This has been followed by decades of growth in gross domestic product, GDP being the only important indicator, and, in a politically incurred statement, the most crucial standard for analyzing and promoting authorities [13]. Due to social tensions, the central government is looking for balanced growth, while local government is still focused on GDP-related growth [43]. This focus on GDP growth displays a particular method of economic development, leading to the maximization of short-term economic growth at the costs of social and environmental sustainability. The main reason for the slow pace of local government regarding GDP growth are the central guidelines for CSR disclosure. This was due to the fact that the local government voluntarily allocates resources, which helps in better performance needed for the national GDP growth [13]. Therefore, the heightened interest of local governments towards economic growth may have diverted the focus of local governments from following the CSR guidelines. Due to this interest, firms have also perceived CSR guidelines as not compulsory to implement. Firms will obey the priorities of local government if it provides the necessary resources like land and infrastructure, and if it remains responsible for enforcing rules, providing permits, levying taxes, overseeing compliance, and ensuring lawfulness [69]. Some research even show that firms who value government policies may involve in adopting the policies to show compliance [70].

Furthermore, provincial government admiration for GDP growth can make firms concentrate more on financial goals as compared to focus on CSR initiatives that lead to a decrease in disclosure quality albeit the existence of annual reports. The embeddedness of growth motivations in a firm's goals can lead to involvement in corporate activities, which reinforces and supports growth motivations [71]. For instance, Sichuan Hongda Company has developed the world's largest chemical plant in 2010 due to intense government commitment towards economic growth [72].

An important and topic relevant interview with CEO of information rating, which evaluates CSR reports in China, disclosed that firms in China only talk about CSR if they have something to show, otherwise these firms remain silent [41]. The content of issued reports is limited to CSR and commitments, meant for the external check, which has an impact on resource allocation and strategic preferences of firms. That is why CSR quality disclosure is compromised due to local government GDP policy. Based on this, the following hypothesis can be formulated:

Hypothesis 1. Firms with a higher level of political embeddedness will issue CSR Reports of lower quality.

\subsection{Resource Base and CSR Disclosure}

Due to deficiency of overt penalties, firms are less likely to conform to standardizing than to powerful pressure [73]. Consequently, some firms will accommodate central government anticipations. Firms under raised inspection can conform further. In the paragraph, these companies are those with political ties to central government and are large in size.

Political embeddedness to the central government can direct the standard effect reveal firms clearly and enhance consideration from the central government $[74,75]$. The national political system in China, i.e., the central government, sustains control over the economy because of ownership through the co-opting corporate director $[76,77]$. The central government commonly nominates directors from inside the political bureaucracy [78]. In these firms, an executive who is selected as part of the national political authority usually also becomes involved in policy conversations [79]. As political embeddedness confers government confirmation for some firms and improves their legitimacy [74], for better access to the support and resources provided by the government, firms' need to conform to the laws of government and in high social standing, it is more likely for firms to collaborate with the 
central government. Contrarily, due to high expectations and more scrutiny by the central government, in case CSR reports are delayed, it can even compromise the firm's legitimacy [80,81].

Bigger firms can resist the burden because they attract more attention from the government and because of inconsistent institutional pressures, which do not apply on a uniform [82,83]. Moreover, these firms are more visible as they are closer to organizational fields and more easily supervised [84]. Due to having more resources, large firms require more compliance from the central government and the public. Small firms, however, can be ignored from the compliance because of low resources. Therefore:

Hypothesis 2. Firms with a higher resource base will report CSR more swiftly and with higher quality.

\subsection{Moderating Role of Political Embeddedness}

According to previous studies, organizations that expected to adopt policies based on external pressure do not implement these policies substantively $[85,86]$. These deviations may also arise because of the inability of organizations to implement the policies [87-89]. However, firms facing higher pressures from the institutional groups and being properly monitored are more likely to implement disclosure appropriately. Because these firms are dependent on resources from the central government, they need to comply with government policies $[73,90]$. Moreover, they are more oriented towards institutional compliance as they are at the risk of losing resources from the central government [70]. Michael Lounsbury [75] reported that public universities in the US are more inclined to comply as compared to private universities because they receive funding from the government. Therefore, these universities have created full-time positions for recycling jobs. In the Chinese context, state-controlled firms frequently depend on political embeddedness in order to get resources whereas other firms rely on market forces [91]. The top executives of state-owned firms also serve political positions, which enable these firms to gain more access to resources [92]. Therefore, the state-controlled firms do not take the risk of involving in low-quality reports. Furthermore, firms with political embeddedness may have more opportunities to get knowledge about the CSR disclosure, which further enhances their implementation capability.

In the same way, large firms' are more at the risk of losing legitimacy and image as compared to smaller firms therefore; they always favor government expectations and the public in relation to low-quality disclosure. If these firms were unable to meet the stakeholders' expectations, then they would lose their legitimacy as well as their ability to get valuable resources [93]. Thus, according to studies on the influence of social movements, large firms are more vulnerable to the demands of stakeholders and activists as they have much stake in maintaining legitimacy [94]. In contrast, the visibility of large firms enables them to enhance reputation amongst stakeholders through their publication of CSR reports [95]. Hence:

Hypothesis 3. Political embeddedness will moderate the relationship between firms' resource base and CSR disclosure strategies, such that the effect of the resource base on a firm CSR disclosure quality will be weaker for firms who have a higher level of Political Embeddedness.

\section{Methodology}

\subsection{Data and Sample}

We collected data from Chinese A-share firms listed on the Shanghai and Shenzhen stock exchanges for the period from 2010 to 2016. We compiled all the data from the Chinese stock market and Accounting Research Database (CSMAR), which is the primary source of information for Chinese listed companies. CSR information items and media exposure data are manually collected. We omitted those firms and years for which data on a certain variable were not available. The data related to provinces were downloaded from provincial government websites and from the Chinese National 
Bureau of Statistics. After removing firms with missing data, financial firms, and those in special treatment, our final sample consists of 21,295 firms, of which 3257 published CSR reports.

\subsection{Empirical Model and Measures}

We used ordinary least squares (OLS) regression model and is as specified as follows:

$$
\begin{gathered}
\operatorname{CSRD} Q_{\mathrm{i}, \mathrm{t}}=\beta_{0}+\beta_{1} P E+\sum_{I=1}^{N} \beta_{\text {controlsi,t }}+\varepsilon_{\mathrm{i}, \mathrm{t}} \\
\operatorname{CSRD} Q_{\mathrm{i}, \mathrm{t}}=\beta_{0}+\beta_{2} R B+\varepsilon+\varepsilon_{\mathrm{i}, \mathrm{t}} \\
\operatorname{CSRDQ} Q_{\mathrm{i}, \mathrm{t}}=\beta_{0}+\beta_{3} P E \times R B+\varepsilon+\varepsilon_{\mathrm{i}, \mathrm{t}}
\end{gathered}
$$

\subsubsection{Dependent Variable}

To test the hypotheses, we used CSR disclosure quality as a dependent variable measured through disclosures of CSR information issued by companies in their annual report. To recognize whether the quality of corporate social responsibility disclosure significantly changes, we first construct a reporting monitor to calculate the information of corporate social responsibilities providing by the CSR reports that we collected from the CSMAR as the primary source of an information database. The CSR report provides information conferring to 10 substances regarding the listed company non-financial performance: (1) protection of shareholders, (I1) including meeting the expectations and requirements of returns and increases, controlling risk, corporate governance, disclosing operational information regularly, shareholders meetings, reports, and communication; (2) safeguarding creditors, (I2) which includes taking care of their debts and providing them with required information so they can oversea and make judgments about the firm's operational and financial position; (3) employee protection, (I3) which includes provision of appropriate wages, health/safety services, career development opportunities, and providing employee training; (4) shipping protection, (I4) which includes keeping and maintaining fair, open, and just procurements, obeying laws while performing contracts, sharing experience, and participating in industrial development; (5) customers protection, (I5) which meant for provision of good quality products and customer management service; (6) environmental protection, (I6) which includes reduction of greenhouse gases, climate control, and protection of eco-systems; (7) public relations, (I7) which includes elements of social responsibility like promoting welfare of people and helping underprivileged members of the society; (8) system construction, (I8) which includes development and enhancement of the CSR system; (9) workplace safety, (I9) which includes ensuring workplace and production safety; and (10) deficiency, (I10) which includes a lack of CSR systems such as communication, training, fragile protection of an employee etc. These terms can adopt ratings ranging from 0 to 3 . From items ranging from 1-10, if it brings no information it will allocate 0 . If it contains qualitative information it will take the value of 1 [96]. Every firm i, in t year, CSR's quality disclosure will represent a CSR rating, which can be quantified on the bases of equation 1 as under; - . - . - - - In this reference, $t$ depicts the as a whole rating for above mentioned 10 items, which are part of CSR report for firm I, for year $t$, and pint rating, which depicts the point for item $j$ of firm $I$ for year $t$. According to the CSR rating definition, higher values indicate higher quality done by the listed firms.

Considering the company's inabilities related to CSR practices or weak CSR systems-like inadequate communication with stakeholders and lack of training, etc.-we use a rating range between 0 and 3 for these items. For items covering 10 substances, if there is no information reported, the rating will be 0 , if there is only general non-quantitative information reported, it will be rated as 1 ; if quantitative information is reported, the rating will be 2 , and if monetary information is reported, 
the rating will be $3[1,96-99]$. For each firm $i$ in the year $t$, we define the quality of corporate social responsibility disclosure as CSR Rating, and it is quantified based on Equation (1) as follows:

$$
C S R \_ \text {Rating }_{\mathrm{i}, \mathrm{t}}=\sum_{j=1}^{10} \operatorname{Rating}\left(I_{i, t}^{j}\right)
$$

In this regard, CSR_Rating $\mathrm{i}_{\mathrm{t}, \mathrm{t}}$ refers to the overall rating of 10 aspects or items included in the CSR disclosure report of firm $i$ at year $t$, whereas Rating $\left(I_{i, t}^{j}\right)$ indicates rating of firm $i$ on items $j$ in year $t$. The higher value of $C S R \_$Rating $_{i, t}$ represents higher CSR disclosure quality.

\subsubsection{Control Variables}

In this study, we included the following control variables: board size, number of independent directors, Tobin's Q (TQ), book to market ratio (BTMA), asset growth, (ROA), return on equity (ROE), board meeting, financial leverage, and board independence to further check the magnitude of impact on CSR reporting quality. Numerous studies have used these control variables for CSR disclosure quality, among them: $[3,18,40,42,100-105]$. Finally, we added industry dummies to control for the specific effect of industry and we included year dummies that are used to control the potential effect of time. For more details, see Table 1.

\subsubsection{Independent Variables}

To test the last two hypotheses, political embeddedness (PE) was consistent with previous literature $[39,106]$ and we created a dummy variable for PE. A firm was assigned a value of 1 if politically embedded and 0 if not. A firm is politically embedded if one of its director, senior officers, or supervisors (i.e., chairman, president, vice president, etc.) is or was a member of the National People's Congress (NPC), a government official, or a member of the Chinese People's Political Consultative Conference (CPPCC) [39,69,80]. According to Bruce Seifert and Barbara R. Bartkus [107], cash flow is described as an available resource for discretionary purposes. Thus, we measured the resource base as total cash flow from different activities including business activities-like operating, investing, and financing $[3,108]$.

In this study, we included the following Control variables: board size, number of independent directors, Tobin's Q, BTMA, asset growth, (ROA), (ROE), board meeting, financial leverage, board independence to further check the magnitude of impact on CSR reporting quality.

Finally, we added industry dummies to control for the specific effect of industry, and we included year dummies that are used to control the potential effect of time. Furthermore, for more details, see Table 1. 
Table 1. Description of variables; CSRDQ-Corporate Social Responsibility Disclosure Quality; PE-Political Embeddedness; RB-Resource Base.

\begin{tabular}{|c|c|c|}
\hline Variables & Abbreviation & Measurement \\
\hline $\begin{array}{l}\text { (1) Corporate social } \\
\text { responsibility disclosure } \\
\text { quality }\end{array}$ & CSRDQ & $\begin{array}{l}\text { The CSR report provides information conferring to ten substances } \\
\text { regarding the listed company's non-financial performance. CSR } \\
\text { report is a dummy variable equal to } 1 \text { if the focal firm has issued a } \\
\text { CSR report in a given year, and it is } 0 \text { otherwise. }\end{array}$ \\
\hline $\begin{array}{l}\text { (2) Political } \\
\text { Embeddedness }\end{array}$ & PE & $\begin{array}{l}\text { Political Embeddedness: The firm assigns value } 1 \text { if it is politically } \\
\text { embedded and } 0 \text { otherwise. A firm is politically embedded if one of } \\
\text { its directors, senior officers, or supervisors (i.e., chairman, president, } \\
\text { vice president, etc.) is or was a member of the National People's } \\
\text { Congress (NPC), a government official, or a member of the Chinese } \\
\text { People's Political Consultative Conference (CPPCC). }\end{array}$ \\
\hline (3) Resource Base & RB & $\begin{array}{l}\text { Resource base as total cash flow from different activities of } \\
\text { business-like operating, investing, and financing. }\end{array}$ \\
\hline (4) Firm Size & FS & Defined as the natural log of total assets. \\
\hline (5) Board Size & BS & The number of directors on the board. \\
\hline (6) Independent Director & ID & The firms will take at least 2 directors as independent directors. \\
\hline (7) Tobin's Q & TQ & $\begin{array}{l}\text { Tobin's Q is the percentage among a physical asset's market value and } \\
\text { its additional value. }\end{array}$ \\
\hline (8) Book to Market Ratio & BTMA & Book to market ratio of shareholders equity. \\
\hline (9) Asset Growth & AG & $\begin{array}{l}\text { Asset Growth of the company is measured as the change in total } \\
\text { assets. }\end{array}$ \\
\hline (10) Return on Assists & $\mathrm{ROA}$ & Total profit is a percentage of total assets. \\
\hline (11) Return on Equity & ROE & The ratio of total profit and percentage of equity. \\
\hline (12) Board Meeting & $\mathrm{BM}$ & The number of meetings in one-year time. \\
\hline (13) Financial Leverage & LEV & The ratio of total debt to the total asset. \\
\hline Year and Industry & YI & $\begin{array}{c}\text { To control the effect of year and industry, we included year and } \\
\text { Industry dummies in all regressions }\end{array}$ \\
\hline
\end{tabular}

\section{Descriptive Statistics and Correlation Matrix}

The descriptive statistics and correlations reported in Table 2 include control variables. The mean value of CSRDQ 5.406 has a standard deviation of 2.505. The average value of firm size (FS), board size (BS), independent director (ID), TQ, BTMA, asset growth (AG), ROA, ROE, board meeting (BM), and financial leverage (LEV), are 23.192, 9.483, 3.493, 1.752, 1.186, 0.166, 0.042, 0.082, 10.215, and 0.509 , respectively. Here, correlation analysis is used to test the existence of multicollinearity by checking the Pearson correlation. All correlation results are below 0.70, which indicates that maximum correlation among the variables does not exceed 0.60 . Therefore, no multicollinearity problem can significantly affect our results. The mean-variance inflation factors (VIFs) was 1.3, which was below the rule-of-thumb cutoff of 10 [3]. The descriptive statistics and correlation can be found in Table 2. 
Table 2. Descriptive statistics and correlation.

\begin{tabular}{|c|c|c|c|c|c|c|c|c|c|c|c|c|c|c|c|c|c|}
\hline Variables & Mean & S.D. & Min & Max & (1) & (2) & (3) & (4) & (5) & (6) & (7) & (8) & (9) & (10) & (11) & (12) & (13) \\
\hline (1) CSRDQ & 5.406 & 2.505 & 1 & 8 & 1.000 & & & & & & & & & & & & \\
\hline (2) PE & 0.105 & 0.306 & 0 & 1 & -1.105 & 1.000 & & & & & & & & & & & \\
\hline (3) RB & 24.83 & 5.508 & 14.557 & 38.975 & -0.050 * & $-0.015 *$ & 1.000 & & & & & & & & & & \\
\hline (4) Firm Size & 23.192 & 1.747 & 18.265 & 30.814 & $0.044 *$ & $-0.073 *$ & $-0.182 *$ & 1.000 & & & & & & & & & \\
\hline (5) Board Size & 9.483 & 2.282 & 4 & 22 & $-0.003 *$ & $-0.002 *$ & $-0.100 *$ & $0.261 *$ & 1.000 & & & & & & & & \\
\hline (6) Independ Direct & 3.493 & 0.839 & 1 & 8 & $0.023 *$ & $0.007 *$ & $-0.092 *$ & $0.315 *$ & $0.593 *$ & 1.000 & & & & & & & \\
\hline (7) Tobin's Q & 1.752 & 1.813 & 0.096 & 33.270 & $-0.081 *$ & $0.068 *$ & $0.119 *$ & -0.468 * & -0.169 * & $-0.143 *$ & 1.000 & & & & & & \\
\hline (8) BTMA & 1.186 & 1.153 & 0.030 & 10.328 & $0.015 *$ & $-0.078 *$ & $-0.110 *$ & $0.580 *$ & $0.114 *$ & $0.137 *$ & $-0.488 *$ & 1.000 & & & & & \\
\hline (9) Asset Growth & 0.166 & 0.343 & -0.828 & 10.888 & $-0.035 *$ & $0.019 *$ & -0.001 & -0.023 * & -0.000 & -0.001 & $0.106 *$ & $-0.073 *$ & 1.000 & & & & \\
\hline (10) ROA & 0.042 & 0.574 & -0.690 & 0.481 & $-0.088 *$ & $0.056 *$ & $-0.058 *$ & $-0.066 *$ & $-0.404 *$ & $0.026^{*}$ & $0.366 *$ & $0.350 *$ & $0.164 *$ & 1.000 & & & \\
\hline (11) ROE & 0.082 & 0.816 & -18.568 & 43.614 & $-0.061 *$ & $0.054 *$ & $-0.059 *$ & 0.084 * & $0.068 *$ & $0.054 *$ & $0.190 *$ & $0.180 *$ & 0.164 * & $0.547^{*}$ & 1.000 & & \\
\hline (12) Board Meeting & 10.215 & 4.790 & 1 & 57 & -0.012 & $-0.020 *$ & $-0.029 *$ & $0.188 *$ & $0.029 *$ & $-0.076 *$ & $-0.105 *$ & $0.205 *$ & $-0.017^{*}$ & -0.127 * & $-0.047 *$ & 1.000 & \\
\hline (13) Fin_Leverage & 0.509 & 0.509 & 0.007 & 1.344 & $0.075^{*}$ & $-0.056^{*}$ & $-0.138 *$ & 0.458 * & $0.115^{*}$ & $0.132 *$ & $-0.477^{*}$ & $-0.607^{*}$ & $-0.477^{*}$ & $-0.085 *$ & $-0.185^{*}$ & 0.241 * & 1.000 \\
\hline
\end{tabular}




\section{Analysis and Results}

Table 3 shows the OLS regression analysis estimates of the influence of political embeddedness and resource based on CSR disclosure quality and control variables. Depending on the respective model, the results reveal a significant relationship between the latent. In model 1 , we tested the relationship between PE and CSRDQ. We found a negative and significant $(t=-4.32, p<0.000)$ coefficient of political embeddedness, which implies that political embeddedness has a negative influence on CSR disclosure quality, thus supporting hypothesis (H1).

Table 3. Influence of PE on the quality of CSR disclosure (ordinary least squares (OLS) regression).

\begin{tabular}{|c|c|c|c|}
\hline Variables & Model 1 & Model 2 & Model 3 \\
\hline CSRDQ & OLS & OLS & OLS \\
\hline PE & $-0.636^{* * *}(-4.32)$ & $-0.514^{* * *}(-3.52)$ & $-0.767^{* * *}(-5.02)$ \\
\hline $\mathrm{RB}$ & - - - - - - & $0.033^{* * *}(9.35)$ & $0.024^{* * *}(6.07)$ \\
\hline Interaction & - - - - - - - - - - & - & $-0.025^{* * *}(5.35)$ \\
\hline Firm Size & $-0.009(-0.21)$ & $-0.016(-0.37)$ & $-0.019(0.44)$ \\
\hline Board Size & $-0.049(-1.43)$ & $-0.049(-1.43)$ & $-0.050(-1.48)$ \\
\hline Independ Direct & $0.081^{* *}(1.93)$ & $0.188^{* *}(2.00)$ & $0.180^{* *}(1.93)$ \\
\hline Tobin's Q & $0.056 *(-1.83)$ & $-0.055 *(-1.82)$ & $-0.054 *(-1.79)$ \\
\hline BTMA & $-0.050(-0.90)$ & $-0.046(-0.85)$ & $-0.049(-0.90)$ \\
\hline Asset Growth & $-0.176(-1.33)$ & $-0.016(-0.12)$ & $-0.078(-0.59)$ \\
\hline ROA & $0.440(0.40)$ & $-0.390(-0.36)$ & $0.267(0.24)$ \\
\hline ROE & $-0.485^{* *}(-1.96)$ & $-0.440^{* *}(-1.80)$ & $-0.439 * *(-1.81)$ \\
\hline Board Meeting & $-0.026^{* * *}(-2.86)$ & $-0.016 *(-1.76)$ & $-0.016^{* *}(-1.82)$ \\
\hline Financial Leverage & $0.647^{* *}(2.04)$ & $0.632 * *(2.02)$ & $0.601^{* *}(1.93)$ \\
\hline Constant & $4.140^{* * *}(4.23)$ & $3.620 * * *(6.80)$ & $3.852 * * *(3.99)$ \\
\hline R-squared & 0.0482 & 0.0732 & 0.0813 \\
\hline
\end{tabular}

Notes: $* * * * * *$, significant at $10 \%, 5 \%$, and $1 \%$, respectively. T-statistics are reported in parentheses. Year and industry dummies are included but not reported here. For a detailed description of variable, see Table 1.

Thus, our results show a decrease in CSRD quality amongst companies with high PE, revealing a negative relationship between political embeddedness and CSR disclosure quality $[3,109]$. Model 2 reveals the estimation result regarding our main hypothesis $(\mathrm{H} 2)$. The coefficient of the resource base indicated a positive and significant relationship with CSR disclosure $(t=9.35, p<0.000)$. Based on the results, hypothesis (H2) is accepted, meaning that firms with a larger resource base will report CSR more swiftly and with higher quality [110]. Furthermore, we applied model 3 with moderation and checked hypothesis 1 (H1) and hypothesis 2 (H2) collectively. Results (see Table 3 and Figure 1) revealed support for the third hypothesis (H3), which suggests that PE played a negative moderating role between resource bases and CSR disclosure quality $(t=5.35, p<0.000)$. Table 3 further shows results regarding control variables. Most control variables had an insignificant relationship with CSR disclosure quality. The result of the control variables is also consistent with the previous [111-113]. 


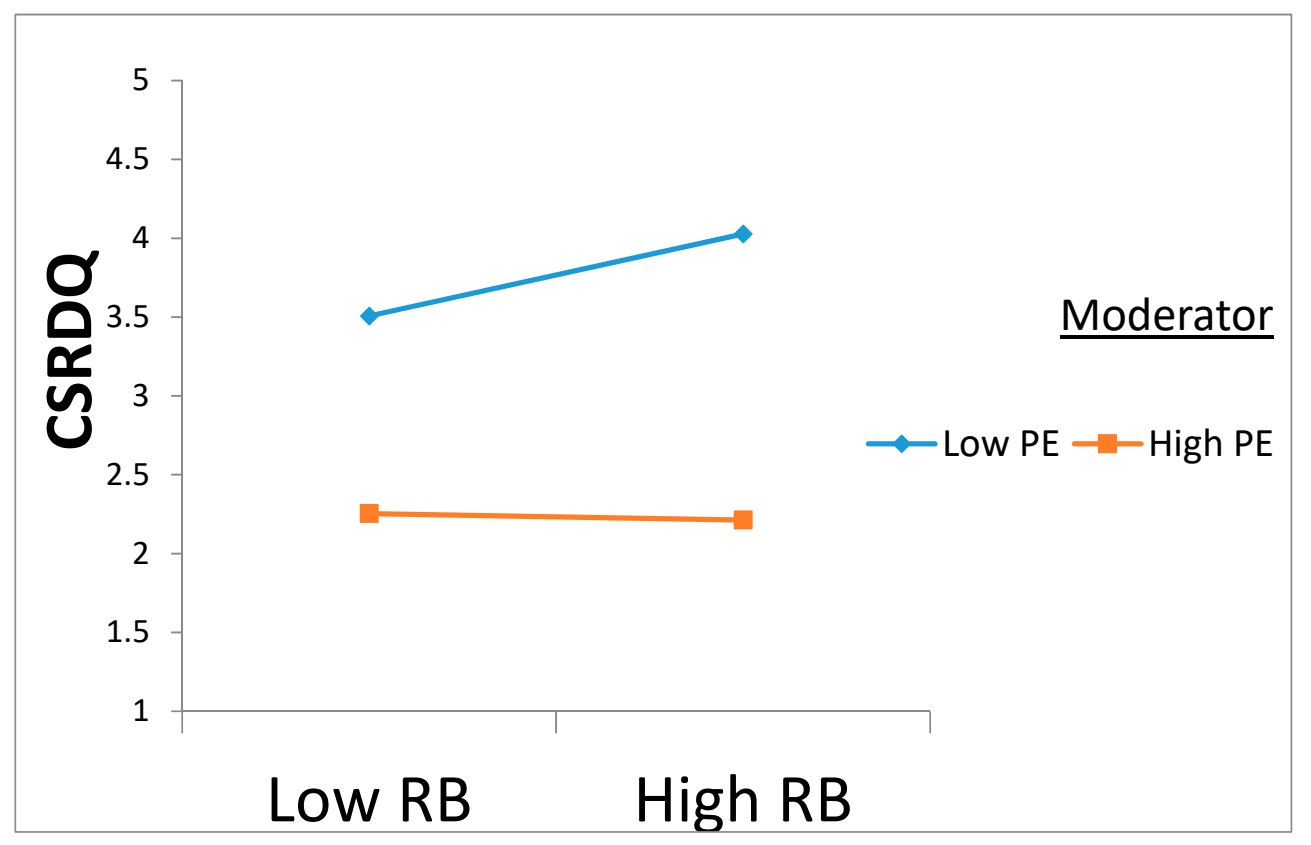

Figure 1. Interaction moderation (PE dampens the positive relationship between RB and CSRDQ).

\section{Endogeneity and Other Robustness Tests}

To further ensure the robustness of our study, our analysis reports a positive and significant relationship between the political embeddedness and CSRD quality. To examine the issue of sample selection bias, we used the Heckman (1979) two-stage analysis. In the first stage, we report our key empirical results of political embeddedness and resource base using OLS regression. We estimate OLS regression for political embeddedness and resource base by regarding all of the control variables as the determinants of political embeddedness and resource base. After estimating this OLS regression for CSRD quality, the second-stage model expecting CSRD quality, which was the indicator from the first-stage model, converts into a risk rate using the inverse Mills ratio [114]. Finally, we estimate our main regression using PE and resource base as the independent variable in Table 4. Models 1-3 shows the results of the two-stage Heckman method. In both models, PE remains negative and significant and the resource base remains positive and significant, which shows that our Heckman results are trustworthy and there is no issue of sample-selection bias. 
Table 4. Additional, endogeneity, and further robustness tests.

\begin{tabular}{|c|c|c|c|}
\hline Variables & Model 1 & Model 2 & Model 3 \\
\hline CSRDQ & OLS & OLS & OLS \\
\hline PE & $-0.636^{* * *}(-4.33)$ & $-0.514^{* * *}(-3.52)$ & $-0.767^{* * *}(-5.03)$ \\
\hline $\mathrm{RB}$ & - - - - - - - - - - & $0.033^{* * *}(9.38)$ & $0.024^{* * *}(6.09)$ \\
\hline Interaction & - - - - - - - - - & - - - - - - - - & $0.025^{* * *}(5.37)$ \\
\hline Firm Size & $-0.009(-0.21)$ & $-0.016(-0.37)$ & $-0.019(-0.44)$ \\
\hline Board Size & $-0.049(-1.44)$ & $-0.049(-1.44)$ & $-0.050(-1.48)$ \\
\hline Independ Direct & $0.184^{* *}(1.94)$ & $0.188^{* *}(2.01)$ & $0.180 * *(1.94)$ \\
\hline Tobin's Q & $0.056 *(-1.84)$ & $-0.055 *(-1.82)$ & $-0.054^{* *}(-1.80)$ \\
\hline BTMA & $-0.050(-0.90)$ & $-0.046(-0.85)$ & $-0.049(-0.90)$ \\
\hline Asset Growth & $-0.176(-1.32)$ & $-0.016(-0.12)$ & $-0.078(-0.59)$ \\
\hline ROA & $0.440(0.40)$ & $-0.390(-0.36)$ & $0.267(0.25)$ \\
\hline ROE & $-0.485^{* *}(-1.97)$ & $-0.440^{* *}(-1.81)$ & $-0.439 * *(-1.81)$ \\
\hline Board Meeting & $-0.026^{* * *}(-2.87)$ & $-0.016 *(-1.76)$ & $-0.016^{* *}(-1.82)$ \\
\hline Financial Leverage & $0.647^{* *}(2.04)$ & $0.632 * *(2.02)$ & $0.601^{* *}(1.93)$ \\
\hline Constant & $4.144^{* * *}(4.24)$ & $3.620 * * *(3.75)$ & $3.852 * * *(4.01)$ \\
\hline Lambda & 0.1235623 & 0.0275016 & 2.42827 \\
\hline R-squared & 0.0482 & 0.0732 & 0.0813 \\
\hline
\end{tabular}

Notes: ${ }^{*}, * * * * *$, significant at $10 \%, 5 \%$, and $1 \%$, respectively. T-statistics are reported in parentheses. Year and industry dummies are included but not reported here. For a detailed description of variable, see Table 1.

\section{Discussion and Conclusions}

This study examined the influence of political embeddedness and resource base on CSRDQ in China. Our results show a decrease in CSR reporting quality amongst companies with high political embeddedness, revealing a negative relationship between political embeddedness and CSR disclosure quality [10,115]. Firms with large government stakes focus more on financial performance and [107] rely on the government for critical decisions [115]. Our findings further strengthen that firms with higher state ownership represent superior social performance because of legitimate and normative influence of state departments at the national level. On the other hand, with the decrease of state ownership, firms' priority of fulfilling social objectives shift toward financial objectives [103].

Further, the special focus of our research inquiry was related to government ownership and political links, which show an effect on registered firms in China and their possibility of publishing quality reports on CSR. The research outcome shows that firms, which are politically embedded, have more tendency to issue reports on CSR, which are not politically embedded. Further results endorse that there is a high ratio of CSRD if firms feature political embeddedness and if firms with various layers of political embeddedness project the strategic options of an organization. We extracted that from the central level of firms where there are more possibilities of doing disclosure on CSR, political embeddedness and government ownership with political links are essentials for increasing the chances of reporting about CSR.

Excitingly, the outcome of our research does not point out that the quality of CSRD of state-owned firms is better than provincial government-owned firms. The possible interpretation of the above-mentioned revelation is the current reform procedure that is more serious in firms owned by the local government. Moreover, firms either owned by local or federal government have to comply with the required standards of quality disclosure on CSR as demanded by the government and community. This becomes the core reason for firms either at the central or local level to incorporate more CSR activities for enhancing the quality of CSR reporting. Thus, the finding of this study is consistent with the theory of political legitimacy, which evidences that political embeddedness enhances the actual value of CSR strategies endorsed by regulators. A more notable thing is that different types and levels of reliability on government support make firms more vulnerable to various kinds of political forces, which ultimately impact initiatives linked to CSR. Regulators modify CSR related practices due to ownership (direct influence) or through political links with executives (indirect influence) of 
organizations. Therefore, we conclude that both government ownership and political links are active approaches for affecting practices related to CSR [91,116].

Accordingly, political embeddedness also influences the trade-off with corporate budget execution representing opportunity costs, undermining the competence of government-induced CSR policies. Efficiency and effectiveness gauges need to consider for an overall evaluation of officially endorsed policies like dissemination of policies linked to practices of CSR. We also need to consider the aspect of efficiency results that claim that regulator interference comes with opportunity cost. Second, this study reveals a positive association between resource base and CSRD quality, suggesting that the direct or indirect accessibility of suitable resources is of essential status in appraising the firm strategy.

Additionally, in line with the resource-based view of the firm, decent financial performance could possibly outcome in the availability of the resources needed for CSR practices, thus offering further chances for firms to become involved with CSR [117]. Due to an absence of financial resources, in responding to the exertion of the force of shareholders, firms might finish up with proper rules and specified obligations that they cannot support in preparation.

\subsection{Policy Implications}

Our results offer useful input for various stakeholders including policy drafters, investors, and partners in Chinese firms linked to practices of CSR. Firstly, the outcome that political embeddedness in the Chinese business environment not only matters but it drives dissemination of functions linked to CSR is significant. Firms' reactions depend on the type and level of a firm's dependency on government support, which is furthered by policy implications. The approach of the Chinese government is different amongst centrally and provincially state-owned firms and, consequently, strategies linked to CSR are different according to the status of political embeddedness. Therefore, the results stress considering opportunity costs related to account policy. If the betterment number of firms publishing CSR reports and CSRD comes at the cost of a decrease in the resource base, the potential social benefit would be negative. This would indicate that the related policy is unfavorable. If the government want the major role of politically embedded firms in China, then this could be achieved through sponsorships of extra training, financial incentive schemes [118], or tax incentives [35].

Another implication of our study could be of value for multinational investors looking to operate in China: political embedded firms at the central level strongly influence strategic decisions. This could possibly affect a foreign investor's choice and agreement of multinational companies (MNCs) to cooperate with their Chinese counterparts. This is also relevant for the business partners and investors of Chinese firms with various facets of value creation [119], as they must endorse CSR practices and possibly support centrally embedded firms, while local or less CSR practicing firms may choose no political embeddedness [120]. Moreover, the most effective way to enhance CSRDQ is by having business partners and investors from Chinese organizations establish an environment in an institutional context where CSR can be initiated [119] and deep comprehension of policies are set by various tiers of government [120]. Finally, we witnessed that corporal philanthropy inclines to link with a higher level of the resource base, though this link is internal. We doubt that firms' CSR information driven philanthropy potentially increases or is equal to the increase of its resource base. We found that firms fighting for reputation sacrifice their resource base and get CSR prizes.

\subsection{Limitations and Future Research}

This study has some limitations, among them two related to proxies of CSR and PE. We incorporated the possibility of issuing CSR reports, CSRDQ, and CSR information in this analysis. This research did not examine the link between other CSR dimensions and PE, like the credibility of CSRDQ information documented in CSR reports. As far as the proxies of political embeddedness are concerned, the assumption backing an empirical aspect is that political connections and government ownership uniformly affect CSRDQ choices of firms. However, the level of political impact may differ between 
firms, government officials can cash in different level of political connection based on their status in social connections [120]. More research could create distinction among tiers of political embeddedness to enhance the influence and dissemination of official signals and policies, like promulgation of CSR actions in China. In addition, another line of research could analyze the governmental roles in facilitating and disseminating firms' CSR practices. More research could include a global sample of firms and Western-based samples to help broaden findings. Enhanced comprehension is crucial and can improve our learning about conditions that facilitate or nurture the advancement of sustainable firms' practices and endorse sustainable values $[10,121]$.

Author Contributions: Conceptualization: F.R. and C.L.V.; methodology: H.B.A.H.; software, F.R.; validation: F.R., C.L.V., H.B.A.H., and C.F.; formal analysis: F.R.; investigation: F.R.; resources, F.R.; data curation: H.B.A.H. and C.F.; writing-original draft preparation, F.R., C.L.V., and H.B.A.H.; writing一review and editing F.R., C.L.V., H.B.A.H., and C.F.; visualization: C.F.; supervision: C.L.V.; project administration: F.R. and C.L.V. All authors have read and agreed to the published version of the manuscript.

Funding: This research received no external funding.

Conflicts of Interest: The authors declare no conflict of interest.

\section{References}

1. Cooper, S.M.; Owen, D.L. Corporate social reporting and stakeholder accountability: The missing link. Account. Organ. Soc. 2007, 32, 649-667. [CrossRef]

2. Xu, S.; Qiao, M.; Che, B.; Tong, P. Regional Anti-Corruption and CSR Disclosure in a Transition Economy: The Contingent Effects of Ownership and Political Connection. Sustainability 2019, 11, 2499. [CrossRef]

3. Marquis, C.; Qian, C. Corporate social responsibility reporting in China: Symbol or substance? Organ. Sci. 2014, 25, 127-148. [CrossRef]

4. Michelson, E. Climbing the dispute pagoda: Grievances and appeals to the official justice system in rural China. Am. Sociol. Rev. 2007, 72, 459-485. [CrossRef]

5. Crane, A.; Matten, D.; Moon, J. Corporations and Citizenship: Business, Responsibility and Society; Cambridge University Press: Cambridge, UK, 2008.

6. Dieleman, M.; Boddewyn, J.J. Using organization structure to buffer political ties in emerging markets: A case study. Organ. Stud. 2012, 33, 71-95. [CrossRef]

7. Tsamenyi, M.; Uddin, S. Introduction to corporate governance in less developed and emerging economies. In In Corporate Governance in Less Developed and Emerging Economies; Emerald Group Publishing Limited: Bingley, UK, 2008; pp. 1-11.

8. Berglöf, E.; Claessens, S. Enforcement and good corporate governance in developing countries and transition economies. World Bank Res. Obs. 2006, 21, 123-150. [CrossRef]

9. Talmud, I.; Mesch, G.S. Market embeddedness and corporate instability: The ecology of inter-industrial networks. Soc. Sci. Res. 1997, 26, 419-441. [CrossRef]

10. Li, Y.; Miao, X.; Zheng, D.; Tang, Y. Corporate Public Transparency on Financial Performance: The Moderating Role of Political Embeddedness. Sustainability 2019, 11, 5531. [CrossRef]

11. Mu, W.; Jiang, X. Political Connections, Innovation Decision Making, and Firm Performance. In Academy of Management Proceedings; Academy of Management: Briarcliff Manor, NY, USA, 2018.

12. Luo, X.; Dong, J. Multilevel Political Embeddedness and Corporate Strategic Discretion. In Academy of Management Proceedings; Academy of Management: Briarcliff Manor, NY, USA, 2013.

13. Wang, X.; Lai, W.; Song, X.; Lu, C. Implementation Efficiency of Corporate Social Responsibility in the Construction Industry: A China Study. Int. J. Environ. Res. Public Health 2018, 15, 2008. [CrossRef]

14. Scott, M.; Balaev, M.; Clarke, B. Political embeddedness in environmental contexts: The intersections of social networks and planning institutions in coastal land use. Environ. Sociol. 2018, 4, 286-298. [CrossRef]

15. Gu, H.; Ryan, C.; Bin, L.; Wei, G. Political connections, guanxi and adoption of CSR policies in the Chinese hotel industry: Is there a link? Tour. Manag. 2013, 34, 231-235. [CrossRef]

16. Whelan, G. The political perspective of corporate social responsibility: A critical research agenda. Bus. Ethics Q. 2012, 22, 709-737. [CrossRef] 
17. Chapple, W.; Moon, J. CSR agendas for Asia. Corp. Soc. Responsib. Environ. Manag. 2007, 14, $183-188$. [CrossRef]

18. Lee, E.; Walker, M.; Zeng, C. Do Chinese government subsidies affect firm value? Account. Organ. Soc. 2014, 39, 149-169. [CrossRef]

19. Lux, S.; Crook, T.R.; Woehr, D.J. Mixing business with politics: A meta-analysis of the antecedents and outcomes of corporate political activity. J. Manag. 2011, 37, 223-247. [CrossRef]

20. Muthuri, J.N.; Gilbert, V. An institutional analysis of corporate social responsibility in Kenya. J. Bus. Ethics 2011, 98, 467-483. [CrossRef]

21. Prechel, H.; Morris, T. The effects of organizational and political embeddedness on financial malfeasance in the largest US corporations: Dependence, incentives, and opportunities. Am. Sociol. Rev. 2010, 75, 331-354. [CrossRef]

22. Hasseldine, J.; ASalama, I.; Toms, J.S. Quantity versus quality: The impact of environmental disclosures on the reputations of UK Plcs. Br. Account. Rev. 2005, 37, 231-248. [CrossRef]

23. Boutin-Dufresne, F.; Savaria, P. Corporate social responsibility and financial risk. J. Investig. 2004, 13, 57-66. [CrossRef]

24. Lee, D.D.; RFaff, W. Corporate sustainability performance and idiosyncratic risk: A global perspective. Financ. Rev. 2009, 44, 213-237. [CrossRef]

25. Cho, S.Y.; Lee, C.; Pfeiffer, R.J., Jr. Corporate social responsibility performance and information asymmetry. J. Account. Public Policy 2013, 32, 71-83. [CrossRef]

26. Clarkson, P.M.; Overell, M.B.; Chapple, L. Environmental reporting and its relation to corporate environmental performance. Abacus 2011, 47, 27-60. [CrossRef]

27. Moroney, R.; Windsor, C.; Aw, Y.T. Evidence of assurance enhancing the quality of voluntary environmental disclosures: An empirical analysis. Account. Financ. 2012, 52, 903-939. [CrossRef]

28. Cox, P.; Wicks, P.G. Institutional interest in corporate responsibility: Portfolio evidence and ethical explanation. J. Bus. Ethics 2011, 103, 143-165. [CrossRef]

29. Hong, H.; Kacperczyk, M. The price of sin: The effects of social norms on markets. J. Financ. Econ. 2009, 93, 15-36. [CrossRef]

30. Petersen, H.L.; Vredenburg, H. Morals or economics? Institutional investor preferences for corporate social responsibility. J. Bus. Ethics 2009, 90, 1. [CrossRef]

31. Plumlee, M.; Brown, D.; Hayes, R.M.; Marshall, R.S. Voluntary environmental disclosure quality and firm value: Further evidence. J. Account. Public Policy 2015, 34, 336-361. [CrossRef]

32. Reverte, C. Determinants of corporate social responsibility disclosure ratings by Spanish listed firms. J. Bus. Ethics 2009, 88, 351-366. [CrossRef]

33. Whelan, G.; Muthuri, J. Chinese state-owned enterprises and human rights: The importance of national and intra-organizational pressures. Bus. Soc. 2017, 56, 738-781. [CrossRef]

34. Hu, Y.Y.; Zhu, Y.; Tucker, J.; Hu, Y. Ownership influence and CSR disclosure in China. Account. Res. J. 2018, 31, 8-21. [CrossRef]

35. Yin, J.; Zhang, Y. Institutional dynamics and corporate social responsibility (CSR) in an emerging country context: Evidence from China. J. Bus. Ethics 2012, 111, 301-316. [CrossRef]

36. Guthrie, D. China and Globalization: The Social, Economic and Political Transformation of Chinese Society; Routledge: New York, NY, USA, 2012.

37. Sun, Q.; Tong, W.H.; Tong, J. How does government ownership affect firm performance? Evidence from China's privatization experience. J. Bus. Financ. Account. 2002, 29, 1-27. [CrossRef]

38. Tu, G.; Lin, B.; Liu, F. Political connections and privatization: Evidence from China. J. Account. Public Policy 2013, 32, 114-135. [CrossRef]

39. Wu, W.; Wu, C.; Rui, O.M. Ownership and the value of political connections: Evidence from China. Eur. Financ. Manag. 2012, 18, 695-729. [CrossRef]

40. Haveman, H.A.; Jia, N.; Shi, J.; Wang, Y. The dynamics of political embeddedness in China. Adm. Sci. Q. 2017, 62, 67-104. [CrossRef]

41. Lau, C.; Lu, Y.; Liang, Q. Corporate social responsibility in China: A corporate governance approach. J. Bus. Ethics 2016, 136, 73-87. [CrossRef]

42. Xu, B.; Zeng, T. Profitability, state ownership, tax reporting and corporate social responsibility: Evidence from Chinese listed firms. Soc. Responsib. J. 2016, 12, 23-31. [CrossRef] 
43. Luo, X.R.; Wang, D.; Zhang, J. Whose call to answer: Institutional complexity and firms' CSR reporting. Acad. Manag. J. 2017, 60, 321-344. [CrossRef]

44. Reid, E.M.; Toffel, M.W. Responding to public and private politics: Corporate disclosure of climate change strategies. Strateg. Manag. J. 2009, 30, 1157-1178. [CrossRef]

45. Short, J.L.; Toffel, M.W. Coerced confessions: Self-policing in the shadow of the regulator. J. Law Econ. Organ. 2007, 24, 45-71. [CrossRef]

46. Oates, W.E. An essay on fiscal federalism. J. Econ. Lit. 1999, 37, 1120-1149. [CrossRef]

47. Bebbington, J.; Larrinaga, C.; Moneva, J.M. Corporate social reporting and reputation risk management. Account. Audit. Account. J. 2008, 21, 337-361. [CrossRef]

48. Barnett, M.L. Stakeholder influence capacity and the variability of financial returns to corporate social responsibility. Acad. Manag. Rev. 2007, 32, 794-816. [CrossRef]

49. Orlitzky, M.; Schmidt, F.L.; Rynes, S.L. Corporate social and financial performance: A meta-analysis. Organ. Stud. 2003, 24, 403-441. [CrossRef]

50. Brown, N.; Deegan, C. The public disclosure of environmental performance information-A dual test of media agenda setting theory and legitimacy theory. Account. Bus. Res. 1998, 29, 21-41. [CrossRef]

51. Darrell, W.; Schwartz, B.N. Environmental disclosures and public policy pressure. J. Account. Public Policy 1997, 16, 125-154. [CrossRef]

52. Gray, R.; Kouhy, R.; Lavers, S. Corporate social and environmental reporting: A review of the literature and a longitudinal study of UK disclosure. Account. Audit. Account. J. 1995, 8, 47-77. [CrossRef]

53. Deegan, C. Introduction: The legitimising effect of social and environmental disclosures-A theoretical foundation. Account. Audit. Account. J. 2002, 15, 282-311. [CrossRef]

54. Dowling, J.; Pfeffer, J. Organizational legitimacy: Social values and organizational behavior. Pac. Sociol. Rev. 1975, 18, 122-136. [CrossRef]

55. Lindblom, C.K. The implications of organizational legitimacy for corporate social performance and disclosure. In Social and Environmental Accounting; SAGE: Los Angeles, CA, USA, 2010.

56. Sun, P.; Mellahi, K.; Thun, E.J. The dynamic value of MNE political embeddedness: The case of the Chinese automobile industry. J. Int. Bus. Stud. 2010, 41, 1161-1182. [CrossRef]

57. Jia, N.J.M.; Review, O. Political strategy and market capabilities: Evidence from the Chinese private sector. Manag. Organ. Rev. 2016, 12, 75-102. [CrossRef]

58. Marquis, C.; Raynard, M. Institutional strategies in emerging markets. Acad. Manag. Ann. 2015, 9, $291-335$. [CrossRef]

59. Peng, M.W.; Luo, Y. Managerial ties and firm performance in a transition economy: The nature of a micro-macro link. Acad. Manag. J. 2000, 43, 486-501.

60. Zheng, W.; Singh, K.; Mitchell, W. Buffering and enabling: The impact of interlocking political ties on firm survival and sales growth. Strateg. Manag. J. 2015, 36, 1615-1636. [CrossRef]

61. Bonardi, J.-P.; Hillman, A.J.; Keim, G.D. The attractiveness of political markets: Implications for firm strategy. Acad. Manag. Rev. 2005, 30, 397-413. [CrossRef]

62. Faccio, M.; Masulis, R.W.; McConnell, J.J. Political connections and corporate bailouts. J. Financ. 2006, 61, 2597-2635. [CrossRef]

63. Khwaja, A.I.; Mian, A. Do lenders favor politically connected firms? Rent provision in an emerging financial market. Q. J. Econ. 2005, 120, 1371-1411. [CrossRef]

64. Hadani, M.; Schuler, D.A. In search of El Dorado: The elusive financial returns on corporate political investments. Strateg. Manag. J. 2013, 34, 165-181. [CrossRef]

65. Okhmatovskiy, I. Performance implications of ties to the government and SOEs: A political embeddedness perspective. J. Manag. Stud. 2010, 47, 1020-1047. [CrossRef]

66. Liu, X.; Anbumozhi, V. Determinant factors of corporate environmental information disclosure: An empirical study of Chinese listed companies. J. Clean. Prod. 2009, 17, 593-600. [CrossRef]

67. Zhang, J.; Marquis, C.; Qiao, K. Do political connections buffer firms from or bind firms to the government? A study of corporate charitable donations of Chinese firms. Organ. Sci. 2016, 27, 1307-1324. [CrossRef]

68. Qian, Y.; Weingast, B.R. Federalism as a commitment to reserving market incentives. J. Econ. Perspect. 1997, 11, 83-92. [CrossRef]

69. Li, H.; Meng, L.; Wang, Q.; Zhou, L.A. Political connections, financing and firm performance: Evidence from Chinese private firms. J. Dev. Econ. 2008, 87, 283-299. [CrossRef] 
70. Okhmatovskiy, I.; David, R.J. Setting your own standards: Internal corporate governance codes as a response to institutional pressure. Organ. Sci. 2012, 23, 155-176. [CrossRef]

71. Ocasio, W. Towards an attention-based view of the firm. Strateg. Manag. J. 1997, 18, 187-206. [CrossRef]

72. Jiang, K.; Li, L.; Feng, Y.; Wang, H.; Wei, B. The Development of China's Primary Copper Smelting Technologies. In Proceedings of the TT Chen Honorary Symposium on Hydrometallurgy, Electrometallurgy and Materials Characterization; Wiley: Maitland, FL, USA, 2012.

73. Oliver, C. Strategic responses to institutional processes. Acad. Manag. Rev. 1991, 16, 145-179. [CrossRef]

74. Baum, J.A.; Oliver, C. Institutional linkages and organizational mortality. Adm. Sci. Q. 1991, 36, 187-218. [CrossRef]

75. Lounsbury, M. Institutional sources of practice variation: Staffing college and university recycling programs. Adm. Sci. Q. 2001, 46, 29-56. [CrossRef]

76. Dickson, B.J. Red Capitalists in China: The Party, Private Entrepreneurs, and Prospects for Political Change; Cambridge University Press: Cambridge, UK, 2003.

77. Lin, N. Capitalism in China: A centrally managed capitalism (CMC) and its future. Manag. Organ. Rev. 2011, 7, 63-96. [CrossRef]

78. Cao, X.; Lemmon, M.; Pan, X.; Qian, M.; Tian, G. Political promotion, CEO incentives, and the relationship between pay and performance. Manag. Sci. 2018, 65, 2947-2965. [CrossRef]

79. Li, H.; Meng, L.; Zhang, J. Why do entrepreneurs enter politics? Evidence from China. Econ. Inq. 2006, 44, 559-578. [CrossRef]

80. Fernández-Gago, R.; Cabeza-García, L.; Nieto, M. Independent directors' background and CSR disclosure. Corp. Soc. Responsib. Environ. Manag. 2018, 25, 991-1001. [CrossRef]

81. Oliver, C.; Holzinger, I. The effectiveness of strategic political management: A dynamic capabilities framework. Acad. Manag. Rev. 2008, 33, 496-520. [CrossRef]

82. Edelman, L.B. Legal ambiguity and symbolic structures: Organizational mediation of civil rights law. Am. J. Sociol. 1992, 97, 1531-1576. [CrossRef]

83. Sun, W.; Zhao, C.; Cho, C.H. Institutional transitions and the role of financial performance in CSR reporting. Corp. Soc. Responsib. Environ. Manag. 2019, 26, 367-376. [CrossRef]

84. Greenwood, R.; Raynard, M.; Kodeih, F.; Micelotta, E.R.; Lounsbury, M. Institutional complexity and organizational responses. Acad. Manag. Ann. 2011, 5, 317-371. [CrossRef]

85. Meyer, J.W.; Rowan, B. Institutionalized organizations: Formal structure as myth and ceremony. Am. J. Sociol. 1977, 83, 340-363. [CrossRef]

86. Zajac, E.J.; Westphal, J.D. The costs and benefits of managerial incentives and monitoring in large US corporations: When is more not better? Strateg. Manag. J. 1994, 15, 121-142. [CrossRef]

87. Bromley, P.; Powell, W.W. From smoke and mirrors to walking the talk: Decoupling in the contemporary world. Acad. Manag. Ann. 2012, 6, 483-530. [CrossRef]

88. Fiss, P.C.; Zajac, E.J. The diffusion of ideas over contested terrain: The (non) adoption of a shareholder value orientation among German firms. Adm. Sci. Q. 2004, 49, 501-534.

89. Weber, K.; Davis, G.F.; Lounsbury, M. Policy as myth and ceremony? The global spread of stock exchanges, 1980-2005. Acad. Manag. J. 2009, 52, 1319-1347. [CrossRef]

90. Voinea, C.L.; van Kranenburg, H. Feeling the squeeze: Nonmarket institutional pressures and firm nonmarket strategies. Manag. Int. Rev. 2018, 58, 705-741. [CrossRef] [PubMed]

91. Ferri, G.; Liu, L.-G. Honor thy creditors beforan thy shareholders: Are the profits of Chinese state-owned enterprises real? Asian Econ. Pap. 2010, 9, 50-71. [CrossRef]

92. Ma, D.; Parish, W.L. Tocquevillian moments: Charitable contributions by Chinese private entrepreneurs. Soc. Forces 2006, 85, 943-964. [CrossRef]

93. Dacin, M.T.; Oliver, C.; Roy, J.P. The legitimacy of strategic alliances: An institutional perspective. Strateg. Manag. J. 2007, 28, 169-187. [CrossRef]

94. Bartley, T.; Child, C. Movements, markets and fields: The effects of anti-sweatshop campaigns on US firms, 1993-2000. Soc. Forces 2011, 90, 425-451. [CrossRef]

95. Wang, H.; Qian, C. Corporate philanthropy and corporate financial performance: The roles of stakeholder response and political access. Acad. Manag. J. 2011, 54, 1159-1181. [CrossRef]

96. Wiseman, J. An evaluation of environmental disclosures made in corporate annual reports. Account. Organ. Soc. 1982, 7, 53-63. [CrossRef] 
97. Dai, J.; Lu, C.; Qi, J. Corporate Social Responsibility Disclosure and Stock Price Crash Risk: Evidence from China. Sustainability 2019, 11, 448. [CrossRef]

98. Li, S.; Liu, C. Quality of corporate social responsibility disclosure and cost of equity capital: Lessons from China. Emerg. Mark. Financ. Trade 2018, 54, 2472-2494. [CrossRef]

99. Wang, J.; Song, L.; Yao, S. The determinants of corporate social responsibility disclosure: Evidence from China. J. Appl. Bus. Res. 2013, 29, 1833-1848. [CrossRef]

100. Chang, L.; Li, W.; Lu, X. Government engagement, environmental policy, and environmental performance: Evidence from the most polluting Chinese listed firms. Bus. Strategy Environ. 2015, 24, 1-19. [CrossRef]

101. Clarkson, P.M.; Li, Y.; Richardson, G.D.; Vasvari, F.P. Revisiting the relation between environmental performance and environmental disclosure: An empirical analysis. Account. Organ. Soc. 2008, 33, 303-327. [CrossRef]

102. Gulzar, M.A.; Cherian, J.; Sial, M.S.; Badulescu, A.; Thu, P.A.; Badulescu, D.; Khuong, N.V. Does Corporate Social Responsibility Influence Corporate Tax Avoidance of Chinese Listed Companies? Sustainability 2018, 10, 4549. [CrossRef]

103. Khan, F.U.; Zhang, J.; Usman, M.; Badulescu, A.; Sial, M.S. Ownership Reduction in state-owned enterprises and corporate social responsibility: Perspective from secondary privatization in China. Sustainability 2019, 11, 1008. [CrossRef]

104. McGuinness, P.B.; Vieito, J.P.; Wang, M. The role of board gender and foreign ownership in the CSR performance of Chinese listed firms. J. Corp. Financ. 2017, 42, 75-99. [CrossRef]

105. Roberts, R.W. Determinants of corporate social responsibility disclosure: An application of stakeholder theory. Account. Organ. Soc. 1992, 17, 595-612. [CrossRef]

106. Chen, C.J.; Li, Z.; Su, X.; Sun, Z. Rent-seeking incentives, corporate political connections, and the control structure of private firms: Chinese evidence. J. Corp. Financ. 2011, 17, 229-243. [CrossRef]

107. Seifert, B.; Morris, S.A.; Bartkus, B.R. Having, giving, and getting: Slack resources, corporate philanthropy, and firm financial performance. Bus. Soc. 2004, 43, 135-161. [CrossRef]

108. Carow, K.; Heron, R.; Saxton, T. Do early birds get the returns? An empirical investigation of early-mover advantages in acquisitions. Strateg. Manag. J. 2004, 25, 563-585. [CrossRef]

109. Muttakin, M.B.; Mihret, D.G.; Khan, A. Corporate political connection and corporate social responsibility disclosures: A neo-pluralist hypothesis and empirical evidence. Account. Audit. Account. J. 2018, 31, 725-744. [CrossRef]

110. Kim, M.C.; Kim, Y.H. CSR and shareholder value in the restaurant industry: The roles of CSR communication through annual reports. Cornell Hospitality Q. 2019, 60, 69-76. [CrossRef]

111. Ali, S.; Zhang, J.; Usman, M.; Khan, F.U.; Ikram, A.; Anwar, B. Sub-National Institutional Contingencies and Corporate Social Responsibility Performance: Evidence from China. Sustainability 2019, 11, 5478. [CrossRef]

112. Garcia-Sanchez, I.-M.; Cuadrado-Ballesteros, B.; Sepulveda, C. Does media pressure moderate CSR disclosures by external directors? Manag. Decis. 2014, 52, 1014-1045. [CrossRef]

113. Lopatta, K.; Jaeschke, R.; Chen, C. Stakeholder engagement and corporate social responsibility (CSR) performance: International evidence. Corp. Soc. Responsib. Environ. Manag. 2017, 24, 199-209. [CrossRef]

114. Van de Ven, W.P.; van Praag, B.M. The demand for deductibles in private health insurance: A probit model with sample selection. J. Econom. 1981, 17, 229-252. [CrossRef]

115. Chen, J.; Yao, X.; Liu, L. Value creation and value maintenance: Investigating the impact of firm capability on political networking. Chin. Manag. Stud. 2019, 13, 318-341. [CrossRef]

116. Ehrnström-Fuentes, M. Delinking legitimacies: A pluriversal perspective on political CSR. J. Manag. Stud. 2016, 53, 433-462. [CrossRef]

117. Surroca, J.; Tribó, J.A.; Waddock, S. Corporate responsibility and financial performance: The role of intangible resources. Strateg. Manag. J. 2010, 31, 463-490. [CrossRef]

118. Yin, J. Institutional drivers for corporate social responsibility in an emerging economy: A mixed-method study of Chinese business executives. Bus. Soc. 2017, 56, 672-704. [CrossRef]

119. Yin, J.; Jamali, D. Strategic corporate social responsibility of multinational companies subsidiaries in emerging markets: Evidence from China. Long Range Plan. 2016, 49, 541-558. [CrossRef] 
120. Hernández-Perlines, F.; Rung-Hoch, N. Sustainable entrepreneurial orientation in family firms. Sustainability 2017, 9, 1212. [CrossRef]

121. Jackson, G.; Bartosch, J.; Avetisyan, E.; Kinderman, D.; Knudsen, J.S. Mandatory non-financial disclosure and its influence on CSR: An international comparison. J. Bus. Ethics 2020, 162, 323. [CrossRef]

(C) 2020 by the authors. Licensee MDPI, Basel, Switzerland. This article is an open access article distributed under the terms and conditions of the Creative Commons Attribution (CC BY) license (http://creativecommons.org/licenses/by/4.0/). 